\title{
Microbial controls on net production of nitrous oxide in a denitrifying woodchip bioreactor
}

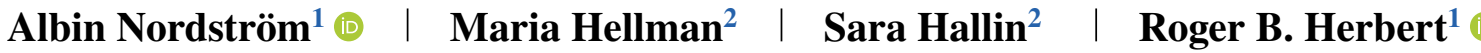

${ }^{1}$ Dep. of Earth Sciences, Uppsala Univ., Villavägen 16, Uppsala SE-752 36, Sweden

${ }^{2}$ Dep. of Forest Mycology and Plant, Pathology, Swedish Univ. of Agricultural Sciences, Box 7026, Uppsala SE-750 07, Sweden

\section{Correspondence}

Roger B. Herbert, Dep. of Earth Sciences, Uppsala Univ., Villavägen 16, SE-75236, Uppsala, Sweden.

Email:roger.herbert@geo.uu.se

Assigned to Associate Editor Michelle Soupir.

Funding information VINNOVA, Grant/Award Number: 2014011334; Luossavaara-Kiirunavaara Aktiebolag (LKAB)

\begin{abstract}
Denitrifying woodchip bioreactors are potential low-cost technologies for the removal of nitrate $\left(\mathrm{NO}_{3}{ }^{-}\right)$in water through denitrification. However, if environmental conditions do not support microbial communities performing complete denitrification, other $\mathrm{N}$ transformation processes will occur, resulting in the export of nitrite $\left(\mathrm{NO}_{2}{ }^{-}\right)$, nitrous oxide $\left(\mathrm{N}_{2} \mathrm{O}\right)$, or ammonium $\left(\mathrm{NH}_{4}{ }^{+}\right)$. To identify the factors controlling the relative accumulation of $\mathrm{NO}_{2}{ }^{-}, \mathrm{N}_{2} \mathrm{O}$, and/or $\mathrm{NH}_{4}{ }^{+}$in denitrifying woodchip bioreactors, porewater samples were collected over two operational years from a denitrifying woodchip bioreactor designed for removing $\mathrm{NO}_{3}{ }^{-}$from mine water. Woodchip samples were collected at the end of the operational period. Changes in the abundances of functional genes involved in denitrification, $\mathrm{N}_{2} \mathrm{O}$ reduction, and dissimilatory $\mathrm{NO}_{3}{ }^{-}$reduction to $\mathrm{NH}_{4}{ }^{+}$were correlated with porewater chemistry and temperature. Temporal changes in the abundance of the denitrification gene nir $S$ were significantly correlated with increases in porewater $\mathrm{N}_{2} \mathrm{O}$ concentrations and indicated the preferential selection of incomplete denitrifying pathways ending with $\mathrm{N}_{2} \mathrm{O}$. Temperature and the total organic carbon/ $/ \mathrm{NO}_{3}{ }^{-}$ratio were strongly correlated with $\mathrm{NH}_{4}{ }^{+}$concentrations and inversely correlated with the ratio between denitrification genes and the genes indicative of ammonification ( nir/nrfA), suggesting an environmental control on $\mathrm{NO}_{3}{ }^{-}$transformations. Overall, our results for a denitrifying woodchip bioreactor operated at hydraulic residence times of 1.0-2.6 d demonstrate the temporal development in the microbial community and indicate an increased potential for $\mathrm{N}_{2} \mathrm{O}$ emissions with time from the denitrifying woodchip bioreactor.
\end{abstract}

\section{1 | INTRODUCTION}

Denitrifying fixed-bed bioreactors are low-cost technologies for the removal of nitrate $\left(\mathrm{NO}_{3}{ }^{-}\right)$from water, which passes

\footnotetext{
Abbreviations: DNRA, dissimilatory $\mathrm{NO}_{3}{ }^{-}$reduction to ammonium; DWB, denitrifying woodchip bioreactor; HRT, hydraulic residence time; NMDS, nonmetric multidimensional scaling; PCR, polymerase chain reaction; qPCR, quantitative polymerase chain reaction; TOC, total organic carbon.
}

through an organic porous material, supplying electrons for the reduction of $\mathrm{NO}_{3}{ }^{-}$to nitrogen gas $\left(\mathrm{N}_{2}\right)$ (Schipper, Robertson, Gold, Jaynes, \& Cameron, 2010). Woodchips are typically used due to their high permeability, moderate reactivity, and capability of providing a carbon (C) and energy source for denitrification (Cameron \& Schipper, 2010; Robertson, 2010; Schipper et al., 2010). However, the release of other nitrogen $(\mathrm{N})$ species (nitrite $\left[\mathrm{NO}_{2}^{-}\right]$, nitric oxide [NO], and the greenhouse gas nitrous oxide $\left[\mathrm{N}_{2} \mathrm{O}\right]$ ) from intermediate steps during denitrification is a potential drawback of

This is an open access article under the terms of the Creative Commons Attribution License, which permits use, distribution and reproduction in any medium, provided the original work is properly cited.

(C) 2020 The Authors. Journal of Environmental Quality published by Wiley Periodicals LLC on behalf of American Society of Agronomy, Crop Science Society of America, and Soil Science Society of America 
denitrifying woodchip bioreactors (DWBs) (Davis, Martin, Moorman, Isenhart, \& Soupir, 2019; Feyereisen et al., 2016). Up to $10 \%$ of the reduced $\mathrm{NO}_{3}{ }^{-}$is exported as $\mathrm{N}_{2} \mathrm{O}$ from DWBs (Davis et al., 2019; Elgood, Robertson, Schiff, \& Elgood, 2010; Feyereisen et al., 2016; Greenan, Moorman, Kaspar, Patkin, \& Jaynes, 2006; Warneke et al., 2011b). The release of these compounds is affected by temperature, $\mathrm{NO}_{3}{ }^{-}$ concentration, dissolved oxygen concentration (Elgood et al., 2010; Grießmeier, Bremges, McHardy, \& Gescher, 2017), and the functional communities involved in the production or reduction of these compounds (Warneke et al., 2011b).

Denitrifiers compete with bacteria performing dissimilatory $\mathrm{NO}_{3}{ }^{-}$reduction to ammonium $\left(\mathrm{NH}_{4}{ }^{+}\right)$(DNRA) for $\mathrm{NO}_{3}{ }^{-}$, and the outcome of this competition determines if $\mathrm{NO}_{3}{ }^{-}$is removed as a gaseous $\mathrm{N}$ species or is converted to aqueous $\mathrm{NH}_{4}{ }^{+}$, thereby affecting the overall $\mathrm{N}$ removal capacity of the DWB. The availability of organic $\mathrm{C}$ in relation to $\mathrm{NO}_{3}{ }^{-}\left(\mathrm{C} / \mathrm{NO}_{3}{ }^{-}\right.$ratio $)$has been shown to control this competition, with high $\mathrm{C} / \mathrm{NO}_{3}{ }^{-}$ratios favoring DNRA (Kraft et al., 2014; Van Den Berg, Van Dongen, Abbas, \& Van Loosdrecht, 2015; Yoon, Cruz-García, Sanford, Ritalahti, \& Löffler, 2015) and low ratios favoring denitrification, which includes an increased risk for the net production of $\mathrm{N}_{2} \mathrm{O}$ (Pan, $\mathrm{Ni}$, Bond, $\mathrm{Ye}, \&$ Yuan, 2013). This is not only because more $\mathrm{N}_{2} \mathrm{O}$ is produced during denitrification than DNRA but also because denitrification can terminate with $\mathrm{N}_{2} \mathrm{O}$ under $\mathrm{NO}_{3}{ }^{-}$-rich conditions (Felgate et al., 2012). For some denitrifiers, $\mathrm{N}_{2} \mathrm{O}$ is always the end product because they do not have the genetic repertoire needed to further reduce $\mathrm{N}_{2} \mathrm{O}$ to $\mathrm{N}_{2}$ and because they, as well as nondenitrifying $\mathrm{N}_{2} \mathrm{O}$ reducers, also affect the net $\mathrm{N}_{2} \mathrm{O}$ emissions (Graf, Jones, \& Hallin, 2014; Hallin, Philippot, Löffler, Sanford, \& Jones, 2018; Jones et al., 2014). In DWBs, $\mathrm{C}$ availability is controlled by woodchip degradation, and the relative availability of different $C$ substrates may change throughout DWB operations (Grießmeier \& Gescher, 2018; Grießmeier et al., 2017; Nordström \& Herbert, 2018). It can therefore be expected that differences in relative abundances of the functional groups involved in the different $\mathrm{N}$ transforming processes develop over time during DWB operation. The proportion between these functional groups ultimately controls the export of $\mathrm{N}$ species from DWBs, but little is known about the temporal development of the $\mathrm{N}$ transforming community and the associated temporal changes in the production of $\mathrm{NO}_{2}^{-}, \mathrm{N}_{2} \mathrm{O}$, and $\mathrm{NH}_{4}{ }^{+}$in DWBs.

In this study, temporal and spatial changes of the abundances of functional groups performing denitrification and DNRA in the porewater were studied with the objectives to relate these patterns with changes in the concentrations of $\mathrm{NO}_{2}{ }^{-}, \mathrm{N}_{2} \mathrm{O}$, and $\mathrm{NH}_{4}{ }^{+}$in the porewater and overall reactor performance in a previously described DWB (Nordström \& Herbert, 2018). We hypothesized that temporal and spatial changes in the genetic potential for denitrification and DNRA, determined as abundances of functional genes in den-

\section{Core Ideas}

- A high degree of spatial and temporal variability for functional gene abundances was noted in porewater.

- Temperature dependence was exhibited especially for the gene nrfA.

- $\mathrm{N}_{2} \mathrm{O}$ production correlated with nirS abundance and $\Sigma$ nir/ $/ \Sigma$ nos $Z$ ratio.

- $\mathrm{TOC} / \mathrm{NO}_{3}{ }^{-}$ratio positively correlated with $n r f A$ abundance and $\mathrm{NH}_{4}{ }^{+}$concentration.

- A truncated denitrification pathway was promoted with time in the bioreactor.

itrifying and DNRA bacteria, control concentrations of $\mathrm{NO}_{2}{ }^{-}$, $\mathrm{N}_{2} \mathrm{O}$, and $\mathrm{NH}_{4}{ }^{+}$and that their abundances are a consequence of changes in $\mathrm{C} / \mathrm{NO}_{3}{ }^{-}$ratios. Because the porewater community is more easily sampled for temporal studies than the woodchip-associated community, we primarily monitored the development of the N-reducing community in the porewater. However, for the last sampling episode, we compared the spatial distribution of the abundance of denitrifying and DNRA bacteria in the woodchip matrix with their spatial distribution in porewater.

\section{2 | MATERIALS AND METHODS}

\section{1 | Study site and DWB system}

The subsurface DWB described by Nordström and Herbert (2018) was constructed at the Kiruna iron ore mine, northern Sweden $\left(67^{\circ} 51^{\prime} \mathrm{N}, 20^{\circ} 13^{\prime} \mathrm{E}\right)$, with the purpose to reduce $\mathrm{NO}_{3}{ }^{-}$concentrations in mine and process water originating from the use of ammonium nitrate-based explosives. For this study, samples from the inlet, outlet, and five porewater sampling points along the bottom centerline of the DWB were used (Supplemental Figure S1).

The DWB was filled with decorticated pine woodchips. To increase the initial abundance of denitrifying microorganisms, digested sewage sludge mixed with water was added while the DWB was filled with woodchips. The center areas of the DWB were capped by glacial till (Supplemental Figure $\mathrm{S} 1$ ) with the intention to restrict oxygen diffusion into the DWB.

Mine drainage from the clarification pond at the mine site was pumped to the DWB, where it entered through a perforated drainage pipe near the surface of the DWB and extending across its width. The hydraulic residence time (HRT) of the DWB was adjusted several times during the operational periods by changing the pump discharge 
(Supplemental Table S1), with $2.6 \mathrm{~d}$ being the most common HRT (varying between 1 and $2.6 \mathrm{~d}$ ). The choice of HRT was based on a previous laboratory-scale experiment where relatively long HRTs at low temperature provided nearly complete removal of $\mathrm{NO}_{3}{ }^{-}$(Nordström \& Herbert, 2017). The DWB was operated for two consecutive field seasons: 22 June to 21 Nov. 2015 (Days 0-151) and 9 May to 21 Oct. 2016 (Days 322-490), referred to as the first and second operational year, respectively.

\section{2 | DWB sampling}

\subsection{1 | Water sampling}

Porewater, inlet water, and outlet water were sampled once a month (referred to as "profile sampling") to analyze water chemistry (Nordström \& Herbert, 2018). Briefly, a peristaltic pump was used for porewater sampling, and the first $\sim 2 \mathrm{~L}$ of water was discarded prior to sample collection to ensure a representative sample. Inlet and outlet water was grab-sampled. For analyses of microbial communities involved in $\mathrm{N}$ transformation processes, water sampled on Days 57, 85, 113, $365,400,428,456$, and 477 was filtered using Sterivex filter units, with $0.22-\mu \mathrm{m}$ Millipore Express polyethersulfone membranes, attached to $60-\mathrm{ml}$ syringes. Inlet water samples from Days 57 and 85 were discarded because of technical problems during sampling. Between 540 and 1,680 ml of water (average, $990 \mathrm{ml}$ ) was required to saturate the Sterivex filter units. The syringes were rinsed in sample water three times prior to filtration, and new polyvinyl chloride plastic tubing for the peristaltic pump was used for each sample. The Sterivex filter units were stored on ice for $\sim 6 \mathrm{~h}$ following collection and frozen at $-20{ }^{\circ} \mathrm{C}$ until DNA extraction.

Denitrifying woodchip bioreactor porewater temperature was obtained from thermistors attached to porewater sampling points at the base of the DWB.

\subsection{2 | Woodchips and sewage sludge media}

Sewage sludge samples used as inoculum were collected in sterile 50-ml plastic tubes at the time of DWB construction and frozen at $-20{ }^{\circ} \mathrm{C}$ until analysis. Woodchips were sampled following the termination of DWB operations (Day 490). The sampling focused on the deepest regions of the DWB because a previous DWB study indicated a significantly greater abundance of 16S rRNA, nirS, nirK, and nosZI genes at the greatest depths in a DWB (Herbert, Winbjörk, Hellman, \& Hallin, 2014). Water was drained from the DWB, and traverse trenches were excavated at 2.7, 11.2, 19.7, 28.2, and $33.9 \mathrm{~m}$ from the inlet (Supplemental Figure S1). Woodchip samples were collected along a center line at bottom depth (corresponding to the five porewater sampling points) and at $0.4 \mathrm{~m}$ above the bottom. Samples were also collected at depths of $11.2,19.7$, and $28.2 \mathrm{~m}$ at $\pm 1.35 \mathrm{~m}$ from the center line and $0.4 \mathrm{~m}$ above bottom (i.e., the deepest possible depth due to the trapezoidal shape of the reactor). At the inlet and outlet, woodchip samples were collected from the surface of the bioreactor. All samples were collected in triplicate. The samples were stored in sterile 50-ml plastic tubes and placed on ice for $\sim 6 \mathrm{~h}$ following collection, frozen at $-10{ }^{\circ} \mathrm{C}$ for $4 \mathrm{~d}$, and stored at $-20{ }^{\circ} \mathrm{C}$ until DNA extraction.

\section{3 | Analyses}

\subsection{1 | Chemical analyses of water samples}

We used porewater chemistry data from Nordström and Herbert (2018). Dissolved $\mathrm{N}_{2} \mathrm{O}$ concentrations were determined via headspace equilibrium and analyzed at the Swedish University of Agricultural Sciences in Uppsala. The dissolved $\mathrm{N}_{2} \mathrm{O}$ concentrations reported in this study differ from those reported in Nordström and Herbert (2018) because errors were identified in the latter study regarding the calculation of dissolved $\mathrm{N}_{2} \mathrm{O}$ from headspace concentrations. See Nordström and Herbert (2018) for additional details on analytical methods.

\subsection{2 | DNA extraction and quantitative real-time polymerase chain reaction}

DNA from the Sterivex filter units was extracted using the MoBio PowerWater Sterivex DNA kit following the manufacturer's instructions, including incubation at $90{ }^{\circ} \mathrm{C}$ (Mobio Laboratories Inc., 2018). For DNA extraction from the woodchips ( $4 \mathrm{~g}$ ) and sewage sludge ( $0.2 \mathrm{~g})$, the DNeasy PowerMax Soil Kit was used according to the manufacturer's instructions (Qiagen $\mathrm{GmbH}$ ). Both the woodchips and digested sewage sludge were freeze-dried prior DNA extraction.

Real-time quantitative polymerase chain reaction (qPCR) was used to determine the abundances of functional genes specific for the denitrification, $\mathrm{N}_{2} \mathrm{O}$ reduction, DNRA, and anammox pathways and used as proxies for the communities performing these reactions. Primers for nirS (Throbäck, Enwall, Jarvis, \& Hallin, 2004) and nirK (Hallin \& Lindgren, 1999; Henry et al., 2004) were used for the denitrifiers, nosZI (Henry, Bru, Stres, Hallet, \& Philippot, 2006) and nosZII (Jones, Graf, Bru, Philippot, \& Hallin, 2013) for the $\mathrm{N}_{2} \mathrm{O}$ reducers, $h d h$ (Schmid et al., 2008) for anammox bacteria, and nrfA (Mohan, Schmid, Jetten, \& Cole, 2004; Welsh, Chee-Sanford, Connor, Löffler, \& Sanford, 2014) for the DNRA communities. These primers, especially the ones 
for nir and $n r f A$, do not cover the extant diversity of each gene (e.g., Bonilla-Rosso, Wittorf, Jones, \& Hallin, 2016; Cannon, Sanford, Connor, Yang, \& Chee-Sanford, 2019), which results in an underestimation of the absolute abundances. However, they allow for a comparative analysis of the relative abundance across samples by sampling a standard subset of each functional group for which functionality is verified (Penton et al., 2013).

The 16S rRNA gene (Muyzer, Dewaal, \& Uitterlinden, 1993) was used as a proxy for the abundance of the total bacterial community. Each $15-\mu \mathrm{l}$ qPCR reaction contained 2-5 ng (water samples) or 0.1-0.3 ng (woodchip samples) of DNA, $0.25-2 \mu \mathrm{M}$ of each primer, $15 \mu \mathrm{g}$ bovine serum albumin, and 1x iQ SYBR Green Supermix (BioRad Laboratories). Two independent quantifications per gene were performed using the BioRad CFX Real-Time System (BioRad Laboratories). Potential PCR inhibition in the samples was tested by spiking each sample with the pGEM-T plasmid (Promega Co.) and amplifying it using plasmid-specific primers. Amplification was compared between samples and nonsample (water control) reactions, and no inhibition was present in the samples with the amounts of DNA extract used. Cycling protocols and primer concentrations are described in the supporting information (Supplemental Table S2).

\subsubsection{Statistical analysis and parameter estimation}

Differences in the abundances of all functional genes and the 16S rRNA genes between porewater (including outlet samples), inlet water, woodchips, and sewage sludge were tested using Dunn's test, which is appropriate for groups with unequal numbers of observations (Zar, 2010), in $\mathrm{R}$ package 'FSA' (Dinno, 2017), which performs a Kruskal-Wallis test (normality could not be assumed based on a Shapiro-Wilks test; Supplemental Table S3) followed by pairwise comparisons. Corrections for multiple comparisons were done by false discovery rate (Benjamini \& Hochberg, 1995). For comparisons between two groups, Wilcoxon rank sum tests were used.

Nonmetric multidimensional scaling (NMDS; using the R package 'vegan' [Oksanen et al., 2018]) was used to illustrate the structural differences in the concatenated $\mathrm{N}$ reducing communities (i.e., based on all functional genes) between samples from the porewater (including outlet samples), inlet water, woodchips, and the inoculum (digested sewage sludge). The abundances of the studied marker genes from each individual sample in the DWB were assumed to represent a specific $\mathrm{N}$-reducing community. Gene abundances were square-root transformed and submitted to Wisconsin double standardization. Then, a community matrix with Bray-Curtis dissimilar- ities was created and the NMDS was run with a maximum of 250 iterations.

We compared the similarity between the $\mathrm{N}$ reducing community in the porewater samples with those in the three potential sources: the inlet water, the woodchip media, and the inoculant sewage sludge. Community matrices based on BrayCurtis dissimilarities were generated for each sample source using the same procedure as described above and compared using a permuted $(n=999)$ analysis of similarity (anosim; R-package 'vegan') (Oksanen et al., 2018).

To identify the selective pressures for changes in $\mathrm{NO}_{2}{ }^{-}$, $\mathrm{N}_{2} \mathrm{O}$, and $\mathrm{NH}_{4}{ }^{+}$concentrations in the DWB, we first tested the correlation between porewater $\mathrm{pH}$, temperature, and solute concentrations $\left(\mathrm{NO}_{3}{ }^{-}, \mathrm{NO}_{2}{ }^{-}, \mathrm{N}_{2} \mathrm{O}, \mathrm{NH}_{4}{ }^{+}\right.$, total organic $\mathrm{C}$ [TOC]) with the $\mathrm{N}$ reducing community structure in the porewater samples using a permuted $(n=999)$ correlation test (envift; R-package 'vegan') (Oksanen et al., 2018). Further, a Spearman's rank correlation analysis with permutation $(10,000)$ tests (R-package 'coin') (Hothurn, Hornik, van de Wiel, \& Zeileis, 2006) was used to correlate $\mathrm{N}$ species in the porewater with individual gene abundances and abundance ratios.

\section{3 | RESULTS}

\section{1 | Porewater chemistry}

The $\mathrm{NO}_{3}{ }^{-}-\mathrm{N}, \mathrm{NO}_{2}{ }^{-}-\mathrm{N}, \mathrm{NH}_{4}{ }^{+}-\mathrm{N}, \mathrm{N}_{2} \mathrm{O}-\mathrm{N}$, and TOC concentrations as well as the $\mathrm{C} / \mathrm{NO}_{3}{ }^{-}$ratio (calculated from TOC and $\mathrm{NO}_{3}{ }^{-}-\mathrm{N}$ concentrations) are presented as a function of time, temperature, and position in the DWB (Figure 1). Nitrate concentrations consistently decreased along the DWB flowpath throughout the operational period (Figure 1a), with the lowest concentrations observed during the warmer periods (Days $1-85,365-428)$. Nitrogen removal rates ranged from 0.14 to $37.5 \mathrm{~g} \mathrm{~N} \mathrm{~m}^{-3}$ (DWB volume) $\mathrm{d}^{-1}$ and have been previously shown to have a temperature dependence (Nordström \& Herbert, 2019). Nitrite concentrations (Figure 1b) were observed up to $11 \mathrm{mg} \mathrm{L}^{-1}$ in the first half of the DWB during the first operational year but were below $1 \mathrm{mg} \mathrm{L}^{-1}$ in the DWB effluent with the exception of first week of operations. Similarly, $\mathrm{NH}_{4}{ }^{+}-\mathrm{N}$ concentrations were elevated throughout the DWB during the first operational year (Figure 1c) but remained relatively constant at $<0.5 \mathrm{mg} \mathrm{L}^{-1}$ during the second operational year. Nitrous oxide (Figure 1d) varied irregularly with sampling position and time but with a tendency for higher concentrations in the first half of the DWB during the summer months (Days 400 and 428). Nitrous oxide production rates, determined from the difference in inlet and outlet $\mathrm{N}_{2} \mathrm{O}-\mathrm{N}$ concentrations, ranged from $\sim 0$ to $3.7 \mathrm{mg} \mathrm{N}_{2} \mathrm{O}-\mathrm{N} \mathrm{m}^{-3} \mathrm{~d}^{-1}$; this can be compared with a production in the range of $12-152 \mathrm{mg}$ 

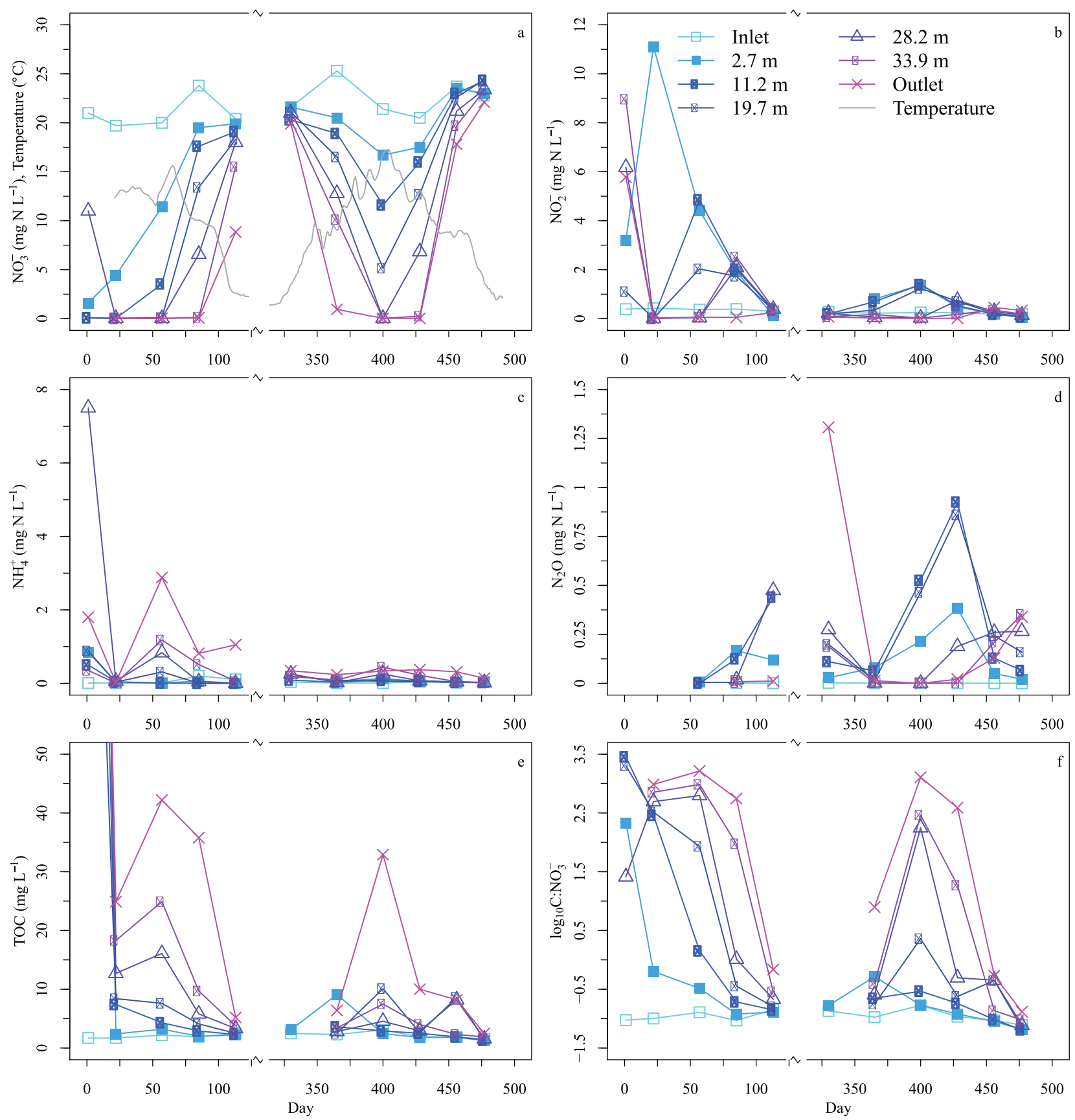

F I G U R E 1 Porewater chemistry in the bioreactor. Concentrations of (a) $\mathrm{NO}_{3}{ }^{-}-\mathrm{N}$, (b) $\mathrm{NO}_{2}{ }^{-}-\mathrm{N}$, (c) $\mathrm{NH}_{4}{ }^{+}-\mathrm{N}$, (d) $\mathrm{N}_{2} \mathrm{O}-\mathrm{N}$, (e) total organic C (TOC), and (f) $\log \mathrm{TOC} / \mathrm{NO}_{3}{ }^{-}-\mathrm{N}$ ratio as a function of time and position in the bioreactor. Position refers to distance from bioreactor inlet. On Day 1 , TOC concentrations were $138-244 \mathrm{mg} \mathrm{L}^{-1}$ (inlet excluded).

$\mathrm{N}_{2} \mathrm{O}-\mathrm{N} \mathrm{m}^{-3} \mathrm{~d}^{-1}$ for DWB's with much shorter HRTs (2-16 h) and composed of hardwood woodchips (Davis et al., 2019). As demonstrated in the porewater data, the average concentrations and concentration ranges of denitrification products (i.e., $\mathrm{NO}_{2}{ }^{-}-\mathrm{N}, \mathrm{N}_{2} \mathrm{O}-\mathrm{N}$ ) when combined from all positions were significantly different between the first and second operational year (Supplemental Figure S2).
Total organic $\mathrm{C}$ concentrations generally decreased during the first operational year and remained $<10 \mathrm{mg} \mathrm{L}^{-1}$ during the second year (with the exception of one sample; Figure 1e). The resultant $\mathrm{TOC} / \mathrm{NO}_{3}{ }^{-}$ratio (Figure 1f) exhibited increasing values with travel distance through the DWB and during the summer months, reflecting primarily the variations in $\mathrm{NO}_{3}-\mathrm{N}$ concentration. 

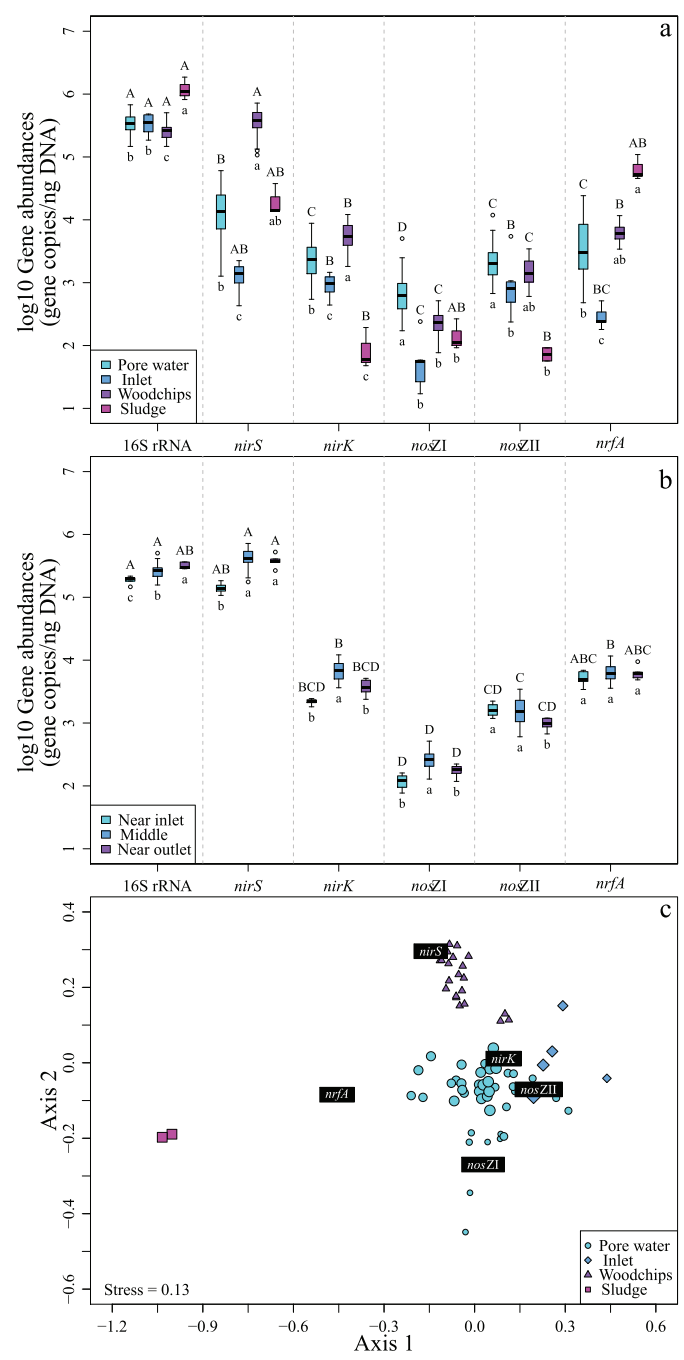

F I G U R E 2 Abundances of the 16S rRNA gene and the functional genes $\operatorname{nir} S$, nirK, nosZI, nosZII, and $n r f A$ in bioreactor samples. (a) Gene abundances in porewater $(n=47-54)$, inlet water $(n=7)$, woodchips corresponding to the porewater sampling points and outlet $(n=18)$, and digested sewage sludge used as inoculum $(n=2-3)$ across the two operational years. Based on Dunn's test $(p<.05)$, uppercase letters indicate differences in gene abundances within sample type, and lowercase letters indicate differences in gene abundance compared with the respective gene abundance in other sample sources. (b) Gene abundances in woodchip samples from $0 \mathrm{~m}$ (bottom) and $0.4 \mathrm{~m}$ above bottom in the bioreactor, with data from the two depths combined. "Near inlet" $(n=6)$ and "Near outlet" $(n=6)$ indicate samples from 2.7 and $33.9 \mathrm{~m}$ from the inlet, along the center line (see Supplemental Figure S1); "Middle" $(n=36)$ indicates samples from 11.2, 19.7, and $28.2 \mathrm{~m}$ from inlet, at both depths along the centerline and at $0.4 \mathrm{~m}$ depth along the sides of the reactor $( \pm 1.35 \mathrm{~m}$ from centerline). Based on Dunn's test $(p<.05)$, uppercase letters indicate differences in gene abundances within each position, and lowercase letters indicate differences in gene abundance compared with the respective gene abundance in other positions. In (a) and (b), empty circles are outliers and lines through boxes signifies median. (c) Nonmetric multidimensional scaling ordination based on Bray-Curtis dissimilarities for the abundances of the functional genes in porewater, inlet water, woodchips (from bottom centerline, inlet, and outlet), and digested sewage sludge used as inoculum. For water samples,

\section{2 | Gene abundances and N-reducing community structure}

The abundances of the total bacterial community and genes coding for the different $\mathrm{N}$ reducing pathways differed among sample types, but the $h d h$ gene coding for anammox was not detected in any of the samples (Figure 2a). An assessment of the difference between woodchip samples collected at different depths indicated that there was not a significant difference ( $p<.05$, one-sided Wilcoxon test) in the abundances of the $16 \mathrm{~S}$ rRNA genes and the functional genes between the two sampling depths, with the exception of nirS. For nirS, there were significantly lower abundances at the bottom compared with $0.4 \mathrm{~m}$ above $(p<.01)$ (data not shown). Regardless, woodchip samples from these two sample depths are considered together for the rest of this study.

There were significant differences in the abundances of the $16 \mathrm{~S}$ rRNA and functional genes between the porewater, inlet water, woodchips, and digested sewage sludge (Figure 2a; Supplemental Table S4). The sample source with the highest abundance of functional genes differed depending on the gene, although gene abundances in the inlet water were most often the lowest among the different sample sources (Figure 2a). For the different genes and sample sources, nirS was most abundant in the woodchips and sludge, whereas $n r f A$ in sludge had the greatest abundance. Among the woodchip samples, the 16S rRNA and nirS abundance varied the most along the flowpath from inlet to outlet and the $n r f A$ abundance did not vary (Figure 2b). nirK and nosZI displayed the same pattern with the highest abundances in the middle section of the reactor, whereas nirS and nosZII had contrasting patterns, with nirS lower at the inlet and nosZII lower at the outlet.

The NMDS analysis (Figure 2c) showed that nirS-type denitrifiers were indicative of the $\mathrm{N}$-reducing community structure in the woodchip media. By contrast, nosZI and nosZII involved in $\mathrm{N}_{2} \mathrm{O}$ reduction were relatively more enriched in the porewater and inlet water samples in comparison to the woodchip media (Figure 2c), and $n r f A$ (DNRA) characterized the N-reducing community in the digested sewage sludge.

Despite differences in absolute abundances, the distribution of gene abundances relative to each other in the porewater was comparable with that in the woodchip media (nirS $>n r f A \geq \operatorname{nirK}>\operatorname{nosZII}>\operatorname{nosZI}$ ) (Figure 2a). However, when comparing the $\mathrm{N}$-cycling community in porewater at Day 477 and woodchip samples from Day 490, there was a significant difference between these two sample pools $(R=.87 ; p=.001)$, demonstrating that these two matrices represent different sampling environments.

increasing symbol sizes imply later sampling dates. Gene names in black boxes denote species scores 


\section{3 | Temporal changes in the N-reducing community and associated biogeochemical changes in the porewater}

We observed differences in gene abundances between the operational years and along the flowpath of the DWB (Figure 3). In general, there was a significant increase in gene abundance between the corresponding periods in the first and second operational year with respect to nirS, nirK, nosZII, and $n r f A$, whereas the total bacterial community remained approximately the same and nosZI decreased significantly (Supplemental Figures S2 and S3). However, the opposite changes in nosZI and nosZII abundances more or less canceled out the total change in potential $\mathrm{N}_{2} \mathrm{O}$ reduction capacity between years. The structure of the $\mathrm{N}$ reducing community in the porewater also changed over time and differed between the two operational years, as shown with NMDS (Figure 4), and the change was significantly associated with changes in porewater concentrations of $\mathrm{NO}_{3}{ }^{-}-\mathrm{N}\left(R^{2}=.34 ; p=.001\right), \mathrm{NO}_{2}{ }^{-}-\mathrm{N}$ $\left(R^{2}=.30 ; p=.003\right), \mathrm{N}_{2} \mathrm{O}-\mathrm{N}\left(R^{2}=.17 ; p=.022\right), \mathrm{NH}_{4}{ }^{+}-$ $\mathrm{N}\left(R^{2}=.14 ; p=.040\right)$, TOC $\left(R^{2}=.28 ; p=.003\right)$, DWB temperature $\left(R^{2}=0.46 ; p=.001\right.$; see also Figure 2$)$, and TOC/ $/ \mathrm{NO}_{3}{ }^{-}$ratio $\left(R^{2}=.3627 ; p=.001\right)$ but not with porewater $\mathrm{pH}\left(R^{2}=.01 ; p=.901\right)$. The differences in the structure of the $\mathrm{N}$ reducing community between years were mainly split in relation to axis 1 (Figure 4), corresponding to changes in the porewater concentrations of $\mathrm{NO}_{2}{ }^{-}-\mathrm{N}$ and $\mathrm{N}_{2} \mathrm{O}-\mathrm{N}$. Although there was no significant difference in the $\mathrm{TOC} / \mathrm{NO}_{3}{ }^{-}$ratio between the two operational years (Supplemental Figure S2), the NMDS demonstrates that the $\mathrm{TOC} / \mathrm{NO}_{3}{ }^{-}$ratio is likely controlled by DWB temperature (Figure 4).

Because the gene abundance data from the first operational year were limited to three sampling dates, it was not possible to make conclusive interpretations of temporal trends during the first year. The investigation of temporal changes over an operational year was hence restricted to data from the second year. During this period, gene copies representing the total bacterial community (Figure 3a) decreased in abundance by approximately $50 \%$. Maximum gene abundances were observed during the summer months (Days 400 and 428) for $n i r S$ and $n r f A$ and to a certain extent $n i r K$, whereas nosZII abundance decreased and nosZI was relatively constant over this period (see Figure 3a-f). Indeed, abundances of $n r f A$ closely followed porewater temperature variations during the second year, with the greatest covariation existing for sampling points towards the outlet (Figure 3f). The abundances of nirS also followed porewater temperature variations, but the peak in abundance appeared to lag behind the temperature maximum (Figure 3b). However, contrary to nrfA, nirS abundance peaked at locations in the first half of the DWB and increased nearest the outlet toward the end of the sampling period.
Among the investigated genes coding for $\mathrm{NO}_{2}{ }^{-}$reductases in denitrifiers (i.e., nirS, nirK), the abundance of nirS consistently exceeded that of nirK in the porewater (Figure 3b,c). The nirS/nirK ratio attained a maximum value at locations close to the inlet and during the summer months (data not shown). Relative to $n r f A$, the abundance of $n i r S+\operatorname{nirK}$ was consistently greater during the two operational years (Figure $3 \mathrm{~g}$ ), with the exception of Day 400 near the outlet where $n r f A>n i r S+$ nirK. The abundance of nirS and nirK genes was also greatly in excess of the sum of the genes coding for $\mathrm{N}_{2} \mathrm{O}$ reductase (i.e., nosZI, nosZII; Figure $3 \mathrm{~h}$ ).

Correlation analyses using data from the second year indicated that significant correlations $\left(r_{\mathrm{s}}>10.61 ; p<.05\right)$ existed among geochemical parameters and between geochemical parameters and gene abundances (Table 1). For example, $\mathrm{N}_{2} \mathrm{O}$ correlated positively with $\mathrm{NO}_{2}{ }^{-}$and negatively with $\mathrm{pH}$.

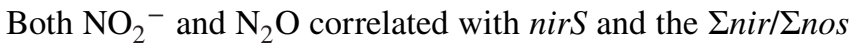
ratio. The dominance of nirS over nirK was positively correlated with $\mathrm{NO}_{2}{ }^{-}, \mathrm{NO}_{3}{ }^{-}$, and $\mathrm{N}_{2} \mathrm{O}$. The $\mathrm{TOC} / \mathrm{NO}_{3}{ }^{-}$ratio correlated with nirK, $n r f A, \mathrm{NH}_{4}{ }^{+}$, and temperature, and $n r f A$ was positively correlated with temperature, $\mathrm{NH}_{4}{ }^{+}$, and TOC and negatively correlated with $\mathrm{NO}_{3}{ }^{-}$. The ratio (nirS + nirK)/nrfA correlated positively with $\mathrm{NO}_{3}{ }^{-}-\mathrm{N}$ and negatively with $\mathrm{TOC} / \mathrm{NO}_{3}{ }^{-}$.

\section{4 | DISCUSSION}

The higher abundance of functional genes involved in the denitrification pathway compared with DNRA and the absence of anammox in both the porewater and woodchip media agrees with denitrification being the major pathway for $\mathrm{NO}_{3}{ }^{-}$reduction and $\mathrm{N}$ removal in the DWB studied here (Nordström \& Herbert, 2018) as well as in DWBs in general (Schipper et al., 2010). Based on gene abundance data, the structures of the N-reducing communities in the woodchips, sludge, inlet water, and the porewater were significantly different from one another in many instances. The original intention of inoculating with digested sewage sludge was to promote the rapid development of a denitrifying community in the woodchip material. However, the sludge also provided a high-abundance source of organisms with the $n r f A$ gene (i.e., genetic capacity for DNRA, an undesired side-reaction in a denitrifying bioreactor). The gene abundances determined in the woodchip samples on Day 490 likely reflect the accumulated contribution from the sludge inoculant, the original community in the woodchips (not analyzed), the inlet water, and the temporal changes of the community in response to selective pressures. However, development of the $\mathrm{N}$-reducing community is mainly determined by the type of substrate used in reactors (Hellman et al., 2020) and, as shown in Figure 4, the porewater TOC concentration, the $\mathrm{TOC} / \mathrm{NO}_{3}{ }^{-}$ratio, and DWB temperature. 

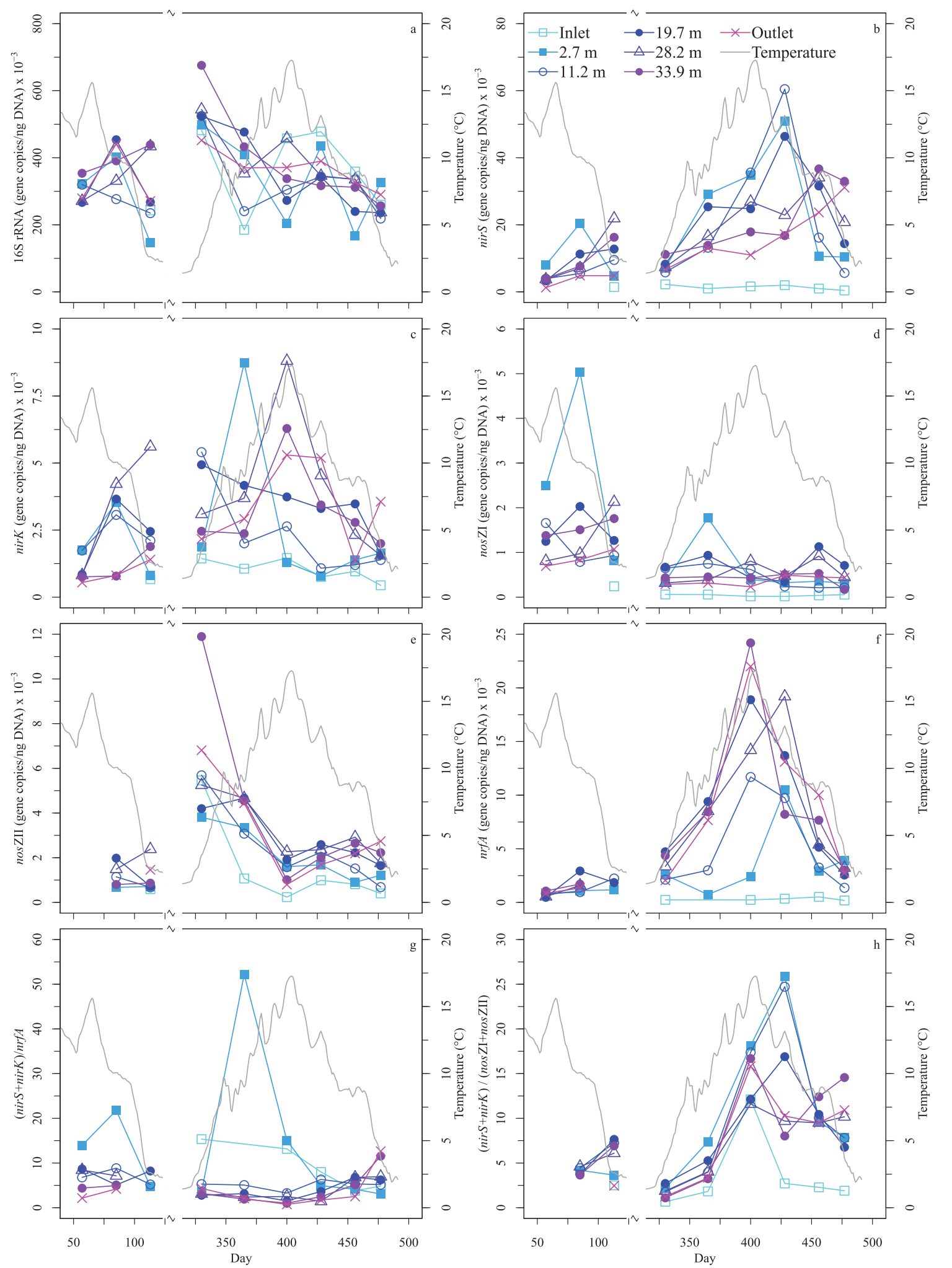

F I G U R E 3 Gene abundances (a-f) and gene abundance ratios ( $\mathrm{g}$ and $\mathrm{h}$ ) as a function of time since start of denitrifying woodchip bioreactor operations and as a function of distance from the inlet. Abundances of (a) 16S rRNA genes and functional genes (b) nirS, (c) nirK, (d) nosZI, (e) nosZII, and (f) $n r f A$. Ratios (g) (nirS + nirK)/nrfA (h) and (nirS + nirK)/(nosZI+nosZII). Bioreactor temperature is plotted on secondary $y$ axis. The $x$ axis corresponds to day of porewater sampling (Days 57, 85, 113, 330, 365, 400, 428, 456, and 477) 


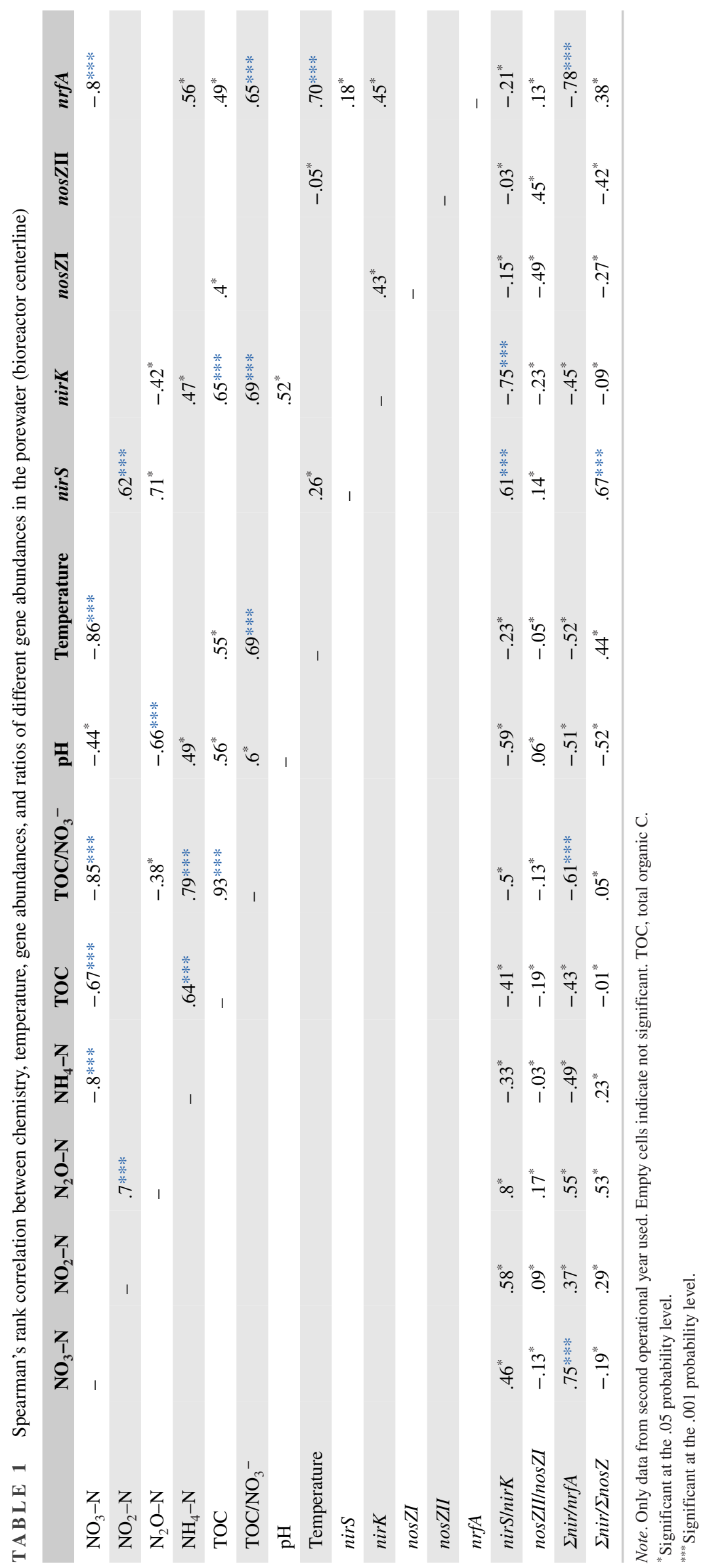




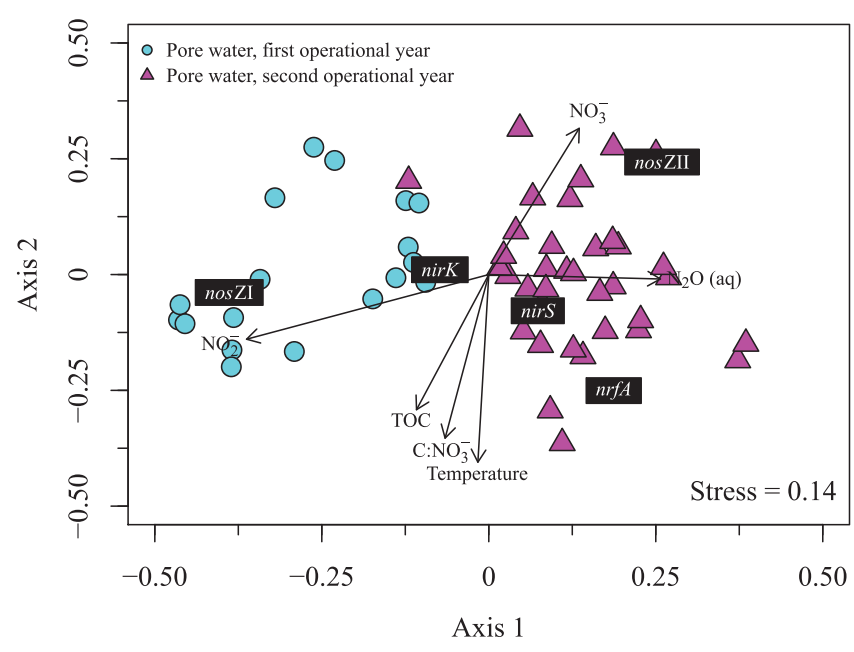

F I G U R E 4 Nonmetric multidimensional scaling ordination based on Bray-Curtis dissimilarities for the abundance of the functional genes nirS, nirK, nosZI, nosZII, and nrfA in porewater samples. Arrows show significant correlations $(p<.05)$ between the $\mathrm{N}$ cycling community structure across samples and porewater chemistry. Gene names in black boxes denote species scores. TOC, total organic C

The surface-bound $\mathrm{N}$ reducing community associated with the woodchips and containing nirS, nirK, and nosZI increased in abundance from the bioreactor inlet to the middle of the DWB (Figure 2b), suggesting that environmental conditions promoting the growth of organisms with nirS, nirK, and nosZI were better in the central region of the DWB compared with conditions closer to the inlet. A similar spatial development in gene abundance was observed in the porewater on Day 477, just prior to woodchip sampling (i.e., nirS and nirK gene abundances increased through bioreactor). Because temperature did not vary greatly within the bioreactor for any given date (data not shown), the increase in nirS and nirK gene abundances along the bioreactor flowpath was likely controlled by the relatively low concentration of organic $\mathrm{C}$, elevated concentrations of $\mathrm{NO}_{3}{ }^{-}$and $\mathrm{NO}_{2}{ }^{-}$, and consequently the low $\mathrm{TOC} / \mathrm{NO}_{3}{ }^{-}$ratio (Figure 1f). These results are contrary to our previous study (Herbert et al., 2014) that indicated a decrease in nirS abundance in a sawdust DWB with distance from the bioreactor inlet; however, this system (Herbert et al., 2014) was $\mathrm{NO}_{3}{ }^{-}$limited in regions further from the inlet but was not $\mathrm{C}$ limited (i.e., high $\mathrm{TOC} / \mathrm{NO}_{3}{ }^{-}$ratio).

Based on the porewater samples (Figures 2 and 3), we clearly detected a shift in the structure of the $\mathrm{N}$ reducing community over time, as characterized by the change in the relative abundances of functional groups (Figure 3; Supplemental Figure S2). The increased abundance of the capacity for $\mathrm{NO}_{2}{ }^{-}$reduction relative to $\mathrm{N}_{2} \mathrm{O}$ reduction during the second operational year suggests a preferential selection of nirS-type denitrifiers with a truncated denitrifying pathway terminating with $\mathrm{N}_{2} \mathrm{O}$. Dissolved $\mathrm{N}_{2} \mathrm{O}$ porewater concentrations were most strongly correlated (Table 1) with $\mathrm{pH}$ and the type of
$\mathrm{NO}_{2}{ }^{-}$reductase (positively with nirS and nirS/nirK ratio and negatively with nirK; c.f. Barrett et al., 2016; Jones et al., 2014) and also with the relative abundance of $\mathrm{NO}_{2}{ }^{-}$reducers to $\mathrm{N}_{2} \mathrm{O}$ reducers ( $\sum n i r / \Sigma n o s Z$ ). Furthermore, the abundances of nirS and nirK (and also $n r f A$ ) during the second operational year (Figure 3) demonstrated a clear temperature dependence, whereas abundances of nosZI and nosZII appeared to be independent of temperature, which led to a correlation between temperature and $\Sigma$ nir/ $\Sigma n o s Z$ (Table 1). Warneke, Schipper, Bruesewitz, McDonald, and Cameron (2011a) showed that an increased abundance of $\mathrm{NO}_{2}{ }^{-}$reducers over $\mathrm{N}_{2} \mathrm{O}$ reducers at higher temperatures, including a relative enrichment in nirS-type to nirK-type denitrifiers, was associated with increased $\mathrm{N}_{2} \mathrm{O}$ emissions in denitrifying bioreactors. Our observations imply an increased genetic potential for the production of $\mathrm{N}_{2} \mathrm{O}$ from DWBs over time and with increasing temperature at HRTs of 1-2.6 d. In addition, the genetic potential for $\mathrm{N}_{2} \mathrm{O}$ production was spatially variable within the bioreactor, implying a geochemical control (e.g., $\mathrm{TOC} / \mathrm{NO}_{3}{ }^{-}$, see below) as well. These implications are important contributions to our general understanding of greenhouse gas emissions from DWBs over longer time scales because they indicate the importance of understanding the temporal development of these systems.

The preferential promotion of denitrifiers with a denitrification pathway terminating with $\mathrm{N}_{2} \mathrm{O}$ may have been an effect of the increased competition for electron donors. The simulations by Nordström and Herbert (2018) suggested a decrease in the export of acetate from the DWB studied here with time from start-up, which is consistent with the observations of other studies (Grießmeier \& Gescher, 2018; Grießmeier et al., 2017). When there is competition for available organic $\mathrm{C}$ by denitrifiers capable of complete denitrification, electrons are preferentially directed to the $\mathrm{NO}_{2}{ }^{-}$reductase rather than the $\mathrm{N}_{2} \mathrm{O}$ reductase (Pan et al., 2013). This suggests that low $\mathrm{TOC} / \mathrm{NO}_{3}{ }^{-}$ratios could lead to the preferential promotion of microorganisms with denitrification pathways truncated to $\mathrm{N}_{2} \mathrm{O}$, in this case nirS denitrifiers. This was supported in this study by the negative correlation between $\mathrm{TOC} / \mathrm{NO}_{3}{ }^{-}$ ratio and the nirS/nirK ratio and its positive correlation with nirK abundances. Promotion of organisms lacking the nosZ gene is also supported by the spatially dependent relationship between $\mathrm{N}_{2} \mathrm{O}$ concentrations and $\Sigma$ nir/ $/$ nos $Z$ (Figures $1 \mathrm{~d}$ and $3 h$ ). Further, clade II nosZ is frequently associated with nondenitrifying bacteria that do not have the genetic makeup needed for $\mathrm{N}_{2} \mathrm{O}$ production (Graf et al., 2014; Jones et al., 2014). The disproportional abundance of nos and nir genes suggests that the denitrification pathway is split among community members. This decoupling of the intermediate steps of denitrification onto several populations would reduce intraorganism competition (Lilja \& Johnson, 2016; Pan et al., 2013). Such decoupling and metabolic specialization among truncated denitrifiers and $\mathrm{N}_{2} \mathrm{O}$ reducers has been inferred from 
metagenomes in tidal sediments and grassland soils (Diamond et al., 2019; Marchant et al., 2018).

The abundance of $n r f A$ genes detected in the porewater suggests DNRA bacteria may be competing for $\mathrm{NO}_{3}{ }^{-}$with the denitrifiers (Figures $2 \mathrm{a}$ and $3 \mathrm{f}$ ). The genetic potential for $\mathrm{NO}_{2}{ }^{-}$reduction relative to DNRA (i.e., $\Sigma$ nir/nrfA) was negatively correlated with the $\mathrm{TOC} / \mathrm{NO}_{3}{ }^{-}$ratio (Table 1 ), in agreement with studies showing that DNRA is favored by high $\mathrm{C} / \mathrm{N}$ ratios (e.g., Kraft et al., 2014). Both temperature and the $\mathrm{TOC} / \mathrm{NO}_{3}{ }^{-}$ratio had an important control on $n r f A$ abundance (Figure $3 \mathrm{f}$ ) and hence $\mathrm{NH}_{4}{ }^{+}-\mathrm{N}$ concentrations, as indicated by significant correlations between these parameters (Table 1). However, the $\mathrm{NH}_{4}{ }^{+}$concentrations were overall low, suggesting limited importance of this unwanted process. Interestingly, many DNRA bacteria are also fermenting (Muyzer \& Stams, 2008; Van Den Berg, Elisário, Kuenen, Kleerebezem, \& van Loosdrecht, 2017), and hence the DNRA bacteria may also contribute to fermentation and thereby support denitrification despite being competitors for $\mathrm{NO}_{3}{ }^{-}$.

\section{5 | CONCLUSIONS}

Denitrification was the major pathway for $\mathrm{NO}_{3}{ }^{-}$reduction and $\mathrm{N}$ removal in the DWB over two operational years at HRTs of 1-2.6 d but was associated with an increased genetic potential for $\mathrm{N}_{2} \mathrm{O}$ production with time. We conclude that $\mathrm{pH}$ and temporal and spatial changes in the relative abundance of different denitrifier genotypes, indicated by abundances of genes involved in different steps in the denitrification pathway, controlled porewater concentrations of $\mathrm{N}_{2} \mathrm{O}$. Bioreactor temperature and $\mathrm{TOC} / \mathrm{NO}_{3}{ }^{-}$ratio had a strong control on the occurrence of bacteria capable of $\mathrm{NO}_{2}{ }^{-}$reduction and those capable of DNRA (preferring high TOC/ $\mathrm{NO}_{3}{ }^{-}$). A spatially variable community, likely dominated by nirS-type denitrifiers with a truncated pathway terminating with $\mathrm{N}_{2} \mathrm{O}$, developed over time in the DWB, where the supply of electron donors from substrate decomposition may be a controlling parameter on community development. Considering the significant differences in DWB chemistry and functional gene abundance between the two operational years, this study highlights the importance of distinguishing between initial variations during a start-up period, which may be extensive in length, and the long-term performance of a DWB.

\section{ACKNOWLEDGMENTS}

This work was supported by the Luossavaara-Kiirunavaara Aktiebolag (LKAB) and VINNOVA, The Swedish Innovation Agency, under Grant 2014-011334. The authors thank Christopher Jones, Carlos Palacin-Lizarbe, and Robert Almstrand for help related to the use of Sterivex filter units. The authors thank the anonymous reviewers for all their comments and advice.

\section{CONFLICTOF INTEREST}

There are no conflicts of interest.

\section{O R C I D}

Albin Nordström (1D https://orcid.org/0000-0002-0311-8368

Roger B. Herbert (10) https://orcid.org/0000-0002-7561-757X

\section{REFERENCES}

Barrett, M., Khalil, M. I., Jahangir, M. M. R., Lee, C., Cardenas, L. M., Collins, G., ... O'Flaherty, V. O. (2016). Carbon amendment and soil depth affect the distribution and abundance of denitrifiers in agricultural soils. Environmental Science and Pollution Research, 23, 78997910. https://doi.org/10.1007/s11356-015-6030-1

Benjamini, Y., \& Hochberg, Y. (1995). Controlling the false discovery rate: A practical and powerful approach to multiple testing. Journal of the Royal Statistical Society Series B-Methodological, 57(1), 289300 .

Bonilla-Rosso, G., Wittorf, L., Jones, C. M., \& Hallin, S. (2016). Design and evaluation of primers targeting genes encoding NO-forming nitrite reductases: Implications for ecological inference of denitrifying communities. Scientific Reports, 6, 39208. https://doi.org/10. 1038/srep39208

Cameron, S. G., \& Schipper, L. A. (2010). Nitrate removal and hydraulic performance of organic carbon for use in denitrification beds. Ecological Engineering, 36(11), 1588-1595. https://doi.org/10.1016/j. ecoleng.2010.03.010

Cannon, J., Sanford, R. A., Connor, L., Yang, W. H., \& Chee-Sanford, J. (2019). Optimization of PCR primers to detect phylogenetically diverse nrfA genes associated with nitrite ammonification. Journal of Microbiological Methods, 160, 49-59. https://doi.org/10.1016/j. mimet.2019.03.020

Davis, M. P., Martin, E. A., Moorman, T. B., Isenhart, T. M., \& Soupir, M. L. (2019). Nitrous oxide and methane production from denitrifying woodchip bioreactors at three hydraulic residence times. Journal of Environmental Management, 242, 290-297. https://doi.org/10.1016/ j.jenvman.2019.04.055

Diamond, S., Andeer, P. F., Li, Z., Crits-Christoph, A., Burstein, D., Anantharaman, K., . . . Banfield, J. F. (2019). Mediterranean grassland soil C-N compound turnover is dependent on rainfall and depth, and is mediated by genomically divergent microorganisms. Nature Microbiology, 4(8), 1356-1367. https://doi.org/10.1038/s41564-019-04 49-y

Dinno, A. (2017). Dunn.test: Dunn's test of multiple comparisons using rank sums. R package version 1.3.5. Retrieved from https://CRAN.Rproject.org/package $=$ dunn.test

Elgood, Z., Robertson, W. D., Schiff, S. L., \& Elgood, R. (2010). Nitrate removal and greenhouse has production in a stream-bed denitrifying bioreactor. Ecological Engineering, 36(11), 1575-1580. https://doi. org/10.1016/j.ecoleng.2010.03.011

Felgate, H., Giannopoulos, G., Sullivan, M. J., Gates, A. J., Clarke, T. A., Baggs, E., ... Richardson, D. J. (2012). The impact of copper, nitrate and carbon status on the emission of nitrous oxide by two species of bacteria with biochemically distinct denitrification pathways. Environmental Microbiology, 14(7), 1788-1800. https://doi.org/10.1111/ j.1462-2920.2012.02789.x

Feyereisen, G. W., Moorman, T. B., Christianson, L. E., Venterea, R. T., Coulter, J. A., \& Tschirner, U. W. (2016). Performance of agricultural residue media in laboratory denitrifying bioreactors at low 
temperatures. Journal of Environmental Quality, 45(3), 779-787. https://doi.org/10.2134/jeq2015.07.0407

Graf, D. R. H., Jones, C. M., \& Hallin, S. (2014). Intergenomic comparisons highlight modularity of the denitrification pathway and underpin the importance of community structure for $\mathrm{N}_{2} \mathrm{O}$ emissions. PLOS ONE, 9(12), e114118. https://doi.org/10.1371/journal.pone.0114118

Greenan, C. M., Moorman, T. B., Kaspar, T. C., Patkin, T. B., \& Jaynes, D. B. (2006). Comparing carbon substrates for denitrification of subsurface drainage water. Journal of Environmental Quality, 35, 824829. https://doi.org/10.2134/jeq2005.0247

Grießmeier, V., Bremges, A., McHardy, A. C., \& Gescher, J. (2017). Investigation of different nitrogen reduction routes and their key microbial players in wood chip-driven denitrification beds. Scientific Reports, 7, 17028. https://doi.org/10.1038/s41598-017-17312-2

Grießmeier, V., \& Gescher, J. (2018). Influence of the potential carbon sources for field denitrification beds on their microbial diversity and the fate of carbon and nitrate. Frontiers in Microbiology, 9, 1313. https://doi.org/10.3389/fmicb.2018.01313

Hallin, S., \& Lindgren, P.-E. (1999). PCR detection of genes encoding nitrite reductase in denitrifying bacteria. Applied and Environmental Microbiology, 65(4), 1652-1657.

Hallin, S., Philippot, L., Löffler, F. E., Sanford, R. A., \& Jones, C. M. (2018). Genomics and ecology of novel $\mathrm{N}_{2} \mathrm{O}$-reducing microorganisms. Trends in Microbiology, 26(1), 43-55. https://doi.org/10.1016/ j.tim.2017.07.003

Hellman, M., Hubalek, V., Juhanson, J., Almstrand, R., Peura, S., \& Hallin, S. (2020). Substrate type determines microbial activity and community composition in bioreactors for nitrate removal by denitrification at low temperature. Science of the Total Environment. https://doi.org/10.1016/j. scitotenv.2020.143023.

Henry, S., Baudoin, E., López-Gutiérrez, J. C., Martin-Laruent, F., Brauman, A., \& Philippot, L. (2004). Quantification of denitrifying bacteria in soils by nirK gene targeted real-time PCR. Journal of Microbiological Methods, 59(3), 327-335. https://doi.org/10.1016/j.mimet. 2004.07.002

Henry, S., Bru, D., Stres, B., Hallet, S., \& Philippot, L. (2006). Quantitative Ddetection of the nos $Z$ gene, encoding nitrous oxide reductase, and comparison of the abundances of 16S rRNA, narG, nirK, and nosZ genes in soils. Applied and Environmental Microbiology, 72(8), 5181-5189. https://doi.org/10.1128/AEM.00231-06

Herbert, R. B., Winbjörk, H., Hellman, M., \& Hallin, S. (2014). Nitrogen removal and spatial distribution of denitrifier and anammox communities in a bioreactor for mine drainage treatment. Water Research, 66, 350-360. https://doi.org/10.1016/j.watres.2014.08.038

Hothurn, T., Hornik, K., van de Wiel, M. A., \& Zeileis, A. (2006). A lego system for conditional inference. American Statistician, 60(3), 257-263. https://doi.org/10.1198/000313006

Jones, C. M., Graf, D. R. H., Bru, D., Philippot, L., \& Hallin, S. (2013). The unaccounted yet abundant nitrous oxide-reducing microbial community: A potential nitrous oxide sink. ISME Journal, 7(2), 417-426. https://doi.org/10.1038/ismej.2012.125

Jones, C. M., Spor, A., Brennan, F. P., Breuil, M. C., Bru, D., Lemanceau, P., .. Philippot, L. (2014). Recently identified microbial guild mediates soil $\mathrm{N}_{2} \mathrm{O}$ sink capacity. Nature Climate Change, 4, 801-805. https://doi.org/10.1038/NCLIMATE2301

Kraft, B., Tegetmeyer, H. E., Sharma, R., Klotz, M. G., Ferdelman, T. G., Hettich, R. L., ... Strous, M. (2014). Nitrogen cycling: The environmental controls that govern the end product of bacterial nitrate respi- ration. Science, 345(6197), 676-679. https://doi.org/10.1126/science. 1254070

Lilja, E. E., \& Johnson, D. R. (2016). Segregating metabolic processes into different microbial cells accelerates the consumption of inhibitory substrates. The ISME Journal, 10, 1568-1578. https://doi. org/10.1038/ismej.2015.243

Marchant, H. K., Tegetmeyer, H. E., Ahmerkamp, S., Holtappels, M., Lavik, G., Graf, J., ... Kuypers, M. M. M. (2018). Metabolic specialization of denitrifiers in permeable sediments controls $\mathrm{N}_{2} \mathrm{O}$ emissions. Environmental Microbiology, 20, 4486-4502. https://doi.org/ 10.1111/1462-2920.14385

MoBio Laboratories Inc. (2018). PowerWater ${ }^{\circledR}$ Sterivex $^{\mathrm{TM}}$ DNA Isolation Kit instruction manual. Retrieved from https://www.qiagen.com/ us/resources/resourcedetail?id=86fe0107-d78b-4a0d-b5fd-3c2cb41 $4 \mathrm{a} 749$ \&lang $=$ en

Mohan, S. B., Schmid, M., Jetten, M., \& Cole, J. (2004). Detection and widespread distribution of the nrfA gene encoding nitrite reduction to ammonia, a short circuit in the biological nitrogen cycle that competes with denitrification. FEMS Microbiology Ecology, 49(3), 433-443. https://doi.org/10.1016/j.femsec.2004.04.012

Muyzer, G., Dewaal, E. C., \& Uitterlinden, A. G. (1993). Profiling of complex microbial populations by denaturing gradient gel electrophoresis analysis of polymerase chain reaction-amplified genes coding for 16S rRNA. Applied and Environmental Microbiology, 59(3), 695-700.

Muyzer, G., \& Stams, A. J. M. (2008). The ecology and biotechnology of sulphate-reducing bacteria. Nature Reviews Microbiology, 6(6), 441454. https://doi.org/10.1038/nrmicro1892

Nordström, A., \& Herbert, R. B. (2017). Denitrification in a lowtemperature bioreactor system at two different hydraulic residence times: Laboratory column studies. Environmental Technology, 38, 1362-1375. https://doi.org/10.1080/09593330.2016.1228699

Nordström, A., \& Herbert, R. B. (2018). Determination of major biogeochemical processes in a denitrifying woodchip bioreactor for treating mine drainage. Ecological Engineering, 110, 54-66. https://doi.org/ 10.1016/j.ecoleng.2017.09.018

Nordström, A., \& Herbert, R. B. (2019). Identification of the temporal control on nitrate removal rate variability in a denitrifying woodchip bioreactor. Ecological Engineering, 127, 88-95. https://doi.org/ 10.1016/j.ecoleng.2018.11.015

Oksanen, J., Guillaume Blanchet, F., Friendly, M., Kindt, R., Legendre, P., McGlinn, D., ... Wagner, H. (2018). vegan: Community ecology package. R package version 2.5-2. Retrieved from https://CRAN.Rproject.org/package $=$ vegan

Penton, C. R., Johnson, T. A., Quensen III J. F., Iwai, S., Cole, J. R., \& Tiedje, J. M. (2013). Functional genes to assess nitrogen cycling and aromatic hydrocarbon degradation: Primers and processing matter. Frontiers in Microbiology, 4, 279. https://doi.org/10.3389/fmicb. 2013.00279

Pan, Y., Ni, B. J., Bond, P. L., Ye, L., \& Yuan, Z. (2013). Electron competition among nitrogen oxides reduction during methanol-utilizing denitrification in wastewater treatment. Water Research, 47(10), 32733281. https://doi.org/10.1016/j.watres.2013.02.054

Robertson, W. D. (2010). Nitrate removal rates in woodchip media of varying age. Ecological Engineering, 36(11), 1581-1587. https://doi. org/10.1016/j.ecoleng.2010.01.008

Schipper, L. A., Robertson, W. D., Gold, A. J., Jaynes, D. B., \& Cameron, S. C. (2010). Denitrifying bioreactors: An approach for reducing 
nitrate loads to receiving waters. Ecological Engineering, 36(11), 1532-1543. https://doi.org 10.1016/j.ecoleng.2010.04.008

Schmid, M. C., Hooper, A. B., Klotz, M. G., Woebken, D., Lam, P., Kuypers, M. M. M., ... Jetten, M. S. M. (2008). Environmental detection of octahaem cytochrome c hydroxylamine/hydrazine oxidoreductase genes of aerobic and anaerobic ammonium-oxidizing bacteria. Environmental Microbiology, 10(11), 31-40-3149. https://doi. org/10.1111/j.1462-2920.2008.01732.x

Throbäck, I. N., Enwall, K., Jarvis, A., \& Hallin, S. (2004). Reassessing PCR primers targeting nirS, nirK and nosZ genes for community surveys of denitrifying bacteria with DGGE. FEMS Microbiology Ecology, 49(3), 401-417. https://doi.org/10.1016/j.femsec.2004.04. 011

Van Den Berg, E. M., Elisário, M. P., Kuenen, J. G., Kleerebezem, R., \& van Loosdrecht, M. C. M. (2017). Fermentative bacteria influence the competition between denitrifiers and DNRA bacteria. Frontiers in Microbiology, 8, 1684. https://doi.org/10.3389/fmicb.2017.01684

Van Den Berg, E. M., Van Dongen, U., Abbas, B., \& Van Loosdrecht, M. C. (2015). Enrichment of DNRA bacteria in a continuous culture. The ISME Journal, 9, 2153-2161. https://doi.org/10.1038/ismej.2015.26

Warneke, S., Schipper, L. A., Bruesewitz, D. A., McDonald, I., \& Cameron, S. (2011a). Rates, controls and potential adverse effects of nitrate removal in a denitrification bed. Ecological Engineering, 37(3), 511-522. https://doi.org/10.1016/j.ecoleng.2010.12.006

Warneke, S., Schipper, L. A., Matiasek, M. G., Scow, K. M., Cameron, S., Bruesewitz, D. A., \& McDonald, I. R. (2011b). Nitrate removal, communities of denitrifiers and adverse effects in different carbon substrates for use in denitrification beds. Water Research, 45(17), 5463-5475. https://doi.org/10.1016/j.watres.2011.08.007

Welsh, A., Chee-Sanford, J. C., Connor, L. M., Löffler, F. E., \& Sanford, R. A. (2014). Refined NrfA phylogeny improves PCR-Based nrfA gene detection. Applied and Environmental Microbiology, 80(7), 2110-2119. https://doi.org/10.1128/AEM.03443-13

Yoon, S., Cruz-García, C., Sanford, R., Ritalahti, K. M., \& Löffler, F. E. (2015). Denitrification versus respiratory ammonification: Environmental controls of two competing dissimilatory $\mathrm{NO}_{3} / \mathrm{NO}_{2}$ reduction pathways in Shewanella loihica strain PV-4. The ISME Journal, 9, 1093-1104. https://doi.org/10.1038/ismej.2014.201

Zar, J. H. (2010). Biostatistical analysis (5th ed.). Upper Saddle River, NJ: Pearson Prentice Hall.

\section{SUPPORTING INFORMATION}

Additional supporting information may be found online in the Supporting Information section at the end of the article.

How to cite this article: Nordström A, Hellman M, Hallin S, Herbert RB. Microbial controls on net production of nitrous oxide in a denitrifying woodchip bioreactor. J. Environ. Qual. 2021;50:228-240. https://doi.org/10.1002/jeq2.20181 